\title{
DETERMINATION OF STARCH BY IODINE COLORIMETRY
}

\author{
K. A. VAinio \\ Department of Animal Husbandry, University of Helsinki
}

Received January 5, 1968

In 1814 de Claubry (ref. Brautlecht, 1953, p. 372) reported that the addition of iodine to starch solutions yields a blue coloration. Later investigations (see comprehensive survey of SAMEC, 1927) have demonstrated the specifity and exceptional sensitiveness of this colour reaction. Nevertheless, competent methods for starch determination based on this principle have not been published before the works of Palohermo (1930, p. 150; 1948, p. 109; Paloheimo and Palohermo 1931, p. 391). The main reason for the discrimination of the iodine colorimetry principle in starch determination lies evidently in the fact that the colour tone which the iodine gives to a starch solution depends both on the starch concentration and the iodine concentration of the solution so that a definite kind of colour is attained only when both concentrations are definite. In addition the colour tone depends on the temperature of the solution. These circumstances make it difficult to use ordinary photometers in iodine colorimetric starch determinations. In addition it is noticeable that when boiled in water only that part of the starch in the ground sample which comes from the broken cells occurs as colloid suspension. The starch of unbroken cells gelatinizes but remains inside the cell walls.

In the method of Paloheimo the starch is converted into dextrins which escape even the unbroken cells. The determination is performed in the following way which, with some minor modifications, also the present author has used.

$1 \mathrm{~g}$ of the material to be analysed is ground with some water in a mortar (even when the material has beforehand been ground with a mill). The sample is then rinsed into a $600-\mathrm{ml}$ beaker which has a mark at $400 \mathrm{ml}$. About $350 \mathrm{ml}$ destilled water is added and the mixture is brought to boil. $20 \mathrm{ml}$ of $1 \mathrm{~N}$ sulphuric acid and boiling water are added up to the mark. The acid normality is now 0.05 . The mixture is boiled for 30 minutes by compensating the loss of evaporation with boiling water, and filtered through a rough filter. The filtering with washing takes about 3 minutes. The filtrate is poured into a $500-\mathrm{ml}$ volumetric flask, the flask is rapidly cooled to room temperature and make up to the volume. This is solution BI. 
Solution AI is made in the same manner as BI but of $500 \mathrm{mg}$ of pure starch, if possible of the same kind as in the analysis sample. Filtration is not necessary but the solution in the volumetric flask must stay hot 3 minutes before cooling.

A $5-\%$ solution of $\mathrm{KJ}$ is saturated with iodine. For the colorimetric use 1 volume of this solution is diluted with 3 volumes of water.

$25 \mathrm{ml}$ of solution $\mathrm{AI}$ is transferred into a $500-\mathrm{ml}$ volumetric flask and about $400 \mathrm{ml}$ of water are poured upon it. $5 \mathrm{ml}$ of the iodine solution is added under simultaneous shaking. The flask is immediately made up to the volume with water and shaken. This is solution AII. Solution BII is made of solution BI in the same manner but the pipetted amount of BI must be large enough to ensure to BII a somewhat greater starch concentration than there is in AII. Thus the colour of BII must be deeper than that of AII. A diluting solution, solution $\mathrm{C}$, for the colorimetric measurement is obtained when $5 \mathrm{ml}$ of iodine solution is diluted with water up to $500 \mathrm{ml}$.

For comparator $17 \mathrm{~cm}$ high optical cells with bottom measures of $40 \mathrm{~mm}$ (optical depth) and $50 \mathrm{~mm}$ are used. Two cells, A and B, are needed. The comparator is home made. Cell A is filled with solution AII and in cell B $100 \mathrm{ml}$ of solution BII is poured. BII in cell B is now diluted with solution $\mathrm{C}$ until $\mathrm{B}$ has reached the colour of $\mathrm{A}$. As the iodine concentration of solution $\mathrm{C}$ is the same as in solutions AII and BII the iodine concentration in cell B remains unchanged during the dilution. When the colour in A and B is the same one may conclude that also the starch concentration is the same. The concentration in A is known and when the liquid volume in B is measured the amount of starch which this cell contains can be calculated. Further, the amounts of starch in the whole BII solution and finally in the BI solution can be calculated. If the starch preparation used for solution AI contains $90 \%$ starch, the solution AII contains $0.045 \mathrm{mg}$ of starch per $1 \mathrm{ml}$.

If the starch used for solution A I is not botanically of the same kind as in the material to be analysed, the result must be corrected using an equivalency coefficient. According to Paloheimo $1 \mathrm{~g}$ of dry wheat starch is colorimetrically equivalent to

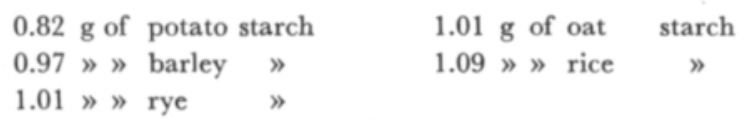

\section{Experiments and results}

Comparator and comparison of the coloured solutions. Paloheimo has used a home made comparator without any lenses and prisms. With this apparatus he has attained very reliable results. The only difficulty is caused by the fact that the two fields of vision which are to be compared are not closely joined to each other. The present author has used a comparator with prisms and lenses (Fig. 1) which creates a circular field of vision in which one half gets the light through the optical cell $\mathrm{A}$ and the other through cell B. This comparator was composed of parts of a Pulfrich photometer no longer in use in the department. The intensity of light can be adjusted by the adjusting drums of the Pulfrich photometer, or by putting frosted glass plates before or behind the optical cells, or by adjusting the current in the lamp. A proper comparator can also be ordered from any skilled optician. When diluting solution BII in the optical cell the author has added the solution $\mathrm{C}$ through a burette. 


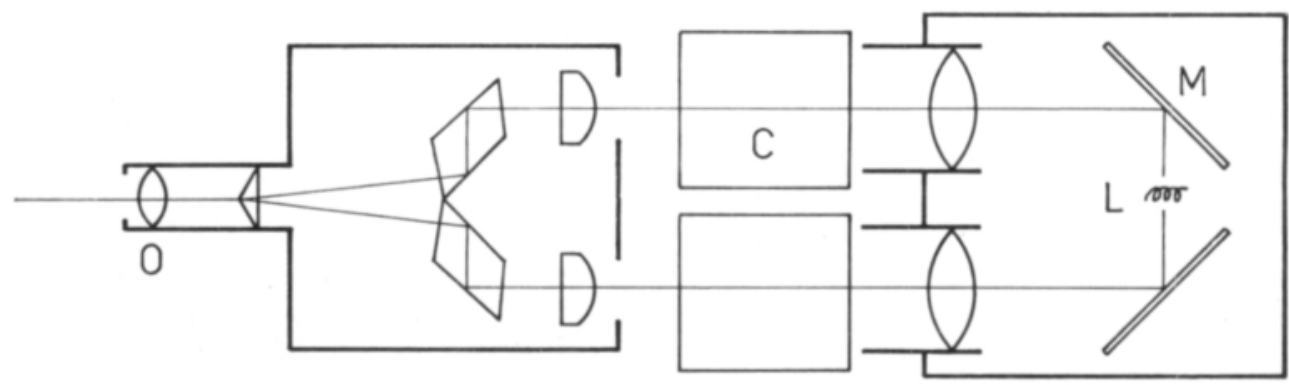

Fig. 1. Schematic picture of the comparator. L lamp, M mirror, C optical cell, O ocular.

I n t e n s it y of boil ing. As in preparing solutions AI and BI (cf. p. 61 and p. 60) the starch is converted into dextrins, it is important that the two solutions are boiled in the same temperature. Differences in atmospheric pressure do not interfere here as both solutions are boiled simultaneously or successively. It is important however, that the two solutions are boiled with about the same intensity. The author observed that when the temperature measured from the middle part of the liquid in the beaker was $100.5^{\circ}$ during very intensive boiling, it was $98.5^{\circ}$ if the boiling was gentle. When solution AI (cf. p. 61) was prepared by gentle boiling and solution BI, made of $500 \mathrm{mg}$ of potato starch, by very intensive boiling, only $85 \%$ of the starch was recovered. Experiments with wheat starch gave approximately the same results. Experiments with barley meal gave $53.2 \%$ starch by gentle boiling but $49.0 \%$ by intensive boiling. These experiments were made in extreme conditions. From the figures in Table 1 it can be concluded that in routine work there is no difficulty in preparing the solutions $\mathrm{AI}$ and $\mathrm{BI}$ in similar conditions.

In all determinations made for this study magnetic mixing has been used. When water is being added into the beaker the mixing should be interrupted in order to make it possible to note the position of the liquid surface.

A cidity during the boiling. The experiments of Palohermo (1931, p. 395) show that the method is not very sensitive to small variations in the normality of the acid solution when preparing the BI solutions. Normal foods are able to cause only insignificant deviations from the normality figure of 0.05 . However, with food mixtures into which e.g. chalk is added one must first determine the neutralizing power of the sample and calculate how much 1- $\mathrm{N} \mathrm{H}_{2} \mathrm{SO}_{4}$ is to be added to obtain a $0.05-\mathrm{N}$ solution. If the sample contains acid it should be extracted beforehand with $80-\%$ ethanol.

Colorimetrical sensitiveness of starch solutions. $500 \mathrm{mg}$ of wheat starch was weighed and solution AI (cf. p. 61) was prepared. As the purity of the starch preparation was $90 \%$, the solution contains $0.9 \mathrm{mg}$ starch per ml. A series of diluted solutions was made by using $100 \mathrm{ml}$ volumetric flasks into which the following amounts of A I were transferred: $1 \mathrm{ml}, 0.5 \mathrm{ml}, 0.3 \mathrm{ml}, 0.2 \mathrm{ml}, 0.1 \mathrm{ml}, 0.05 \mathrm{ml}$ and $0 \mathrm{ml}$. In each flask $1 \mathrm{ml}$ of iodine solution (for colorimetric use, p. 61) was added, and the flasks were made up to the volume. Using the comparator the colour of the solutions was compared with the colour of the $0-\mathrm{ml}$ solution. This comparation was performed both in $20^{\circ}$ and $3^{\circ}$. The iodine concentration of the solutions is the same as that in the solutions AII and BII in the method of Paloheimo. 
A similar series was prepared and studied with potato starch the purity of which was $86.5 \%$. Two further series were studied, one with wheat starch and the other with potato starch, in the preparing of which no acid was used but only $1 / 2$ hours' boiling in water. These series were studied only in $20^{\circ}$.

The purpose of these experiments was to investigate the utmost concentration limits of starch which still cause a visible change in the colour of the iodine solution. These minimum concentrations were:

\begin{tabular}{|c|c|c|c|c|c|c|c|}
\hline 1. Wheat & $\operatorname{tar}$ & oil & in & water & $20^{\circ}$ & 0.18 & $\mathrm{mg} / 100 \mathrm{ml}$ \\
\hline 2. " & $"$ & $"$ & 》 & acid & $20^{\circ}$ & 0.27 & $"$ \\
\hline 3. & $"$ & " & » & $"$ & $3^{\circ}$ & 0.09 & $n$ \\
\hline 4. Potato & $"$ & $n$ & » & water & $20^{\circ}$ & 0.18 & " \\
\hline 5. 》 & $"$ & " & & acid & $20^{\circ}$ & 0.09 & $"$ \\
\hline " & $"$ & $»$ & " & $»$ & $3^{\circ}$ & $0.05-0.09$ & $"$ \\
\hline
\end{tabular}

Influence of cellulose, ethanol, sugars and proteins. In some cases starch may be determined of the residue on a filter paper. It is therefore important to know whether it is possible to prepare solution BI (cf. p. 60) by boiling the residue together with the paper. In order to study this point a BI solution was prepared using $100 \mathrm{mg}$ of wheat starch and a Whatman No. 4 filter paper. The paper $(\varnothing 15 \mathrm{~cm}, 1,5 \mathrm{~g})$ was torn to pieces. All the starch was recovered by iodine colorimetry.

If the material to be analysed is to be extracted with ethanol one should know to what extent the ethanol is to be removed from the material, by evaporation or by washing with water, before the starch determination. For studying this question $1 \mathrm{~g}$ of barley meal was boiled in $80-\%$ ethanol for 4 hours. After filtration through a Whatman No. 4 paper (Ø $15 \mathrm{~cm}$ ) the residue with the filter paper was allowed to stand for some minutes and was then boiled as usual when preparing solution BI. Colorimetrically $537 \mathrm{mg}$ of starch per $1 \mathrm{~g}$ of barley dry matter were recovered as the mean of two determinations. When the starch was determined from barley meal without an ethanol extraction the corresponding figure was 530. Evidently the ethanol content in solution B I was so small that it could not interfere with the hydrolysis of the starch, and in solution BII so low that it was not able to depress significantly the iodine absorption of the dextrine solution. However, when the concentration of starch in BI is low, a greater amount of this solution should be taken for solution BII. In such a case it is advisable to leave the solution to boil for about 30 minutes before the addition of the acid.

When the BI solution was prepared from $100 \mathrm{mg}$ of wheat starch with $1 \mathrm{~g}$ of saccharose added, the starch was entirely recovered. As the $1 / 2$ hours' boiling in $0.05-\mathrm{N} \mathrm{H}_{2} \mathrm{SO}_{4}{ }^{-}$ solution is sufficient for the invertion of saccharose one may conclude that even glucose and fructose do not have a disturbing influence on colorimetric starch determination. It was also proved that maltose and lactose have no such influence.

As some proteins and simpler nitrogenous compounds are able to bind iodine it seemed reasonable to examine whether such substances could possibly interfere with the starch determination. For that purpose a BI solution was prepared by using $100 \mathrm{mg}$ of wheat starch and $20 \mathrm{ml}$ of skim milk. The amount of milk used contained about $650 \mathrm{mg}$ of protein. All the starch was recovered. The result was the same when $250 \mathrm{mg}$ of gelatine was used. 
However, when the amount of gelatine was $1 \mathrm{~g}$ the solution BII turned a greenish colour and the colorimetric comparation was very difficult. The same result was obtained with a casein preparation intended for food mixtures of laboratory animals. Evidently this casein was partially hydrolysed. Likewise, when about $3 \mathrm{~g}$ of meat poor in fat was boiled with $100 \mathrm{mg}$ of starch the greensih colour appeared and the colorimetric comparation was not possible.

However, judging by the figures in Table 1 plant proteins seem not to have a disturbing influence upon iodine colorimetric starch determination.

Iodine colorimetric method compared with the amylog l u c o s id a s e met ho d. In this department SALo (1968, p. 41) has worked out a very reliable method in which the starch is converted with amyloglucosidase into glucose and

Table 1. Starch percentages obtained by the iodine colorimetric method compared with those obtained by the amyloglucosidase method of Salo ( $\%$ of dry matter).

\begin{tabular}{lrrrr}
\hline & \multicolumn{2}{c}{$\begin{array}{c}\text { Colorimetric method } \\
\text { b }\end{array}$} & mean & $\begin{array}{c}\text { Amyloglucosi- } \\
\text { dase method } \\
\text { mean }\end{array}$ \\
\hline 1. Wheat kernels & & & & 58.2 \\
2. Rye & & & & 57.0 \\
3. Barley & 57.7 & 57.3 & 57.5 & 53.6 \\
4. Oat & 54.5 & 54.7 & 54.6 & 48.7 \\
5. Wheat bran & 53.7 & 53.1 & 53.4 & 21.5 \\
6. Peas & 48.5 & 48.1 & 48.3 & 40.2 \\
7. Peanut cake & 22.2 & 21.9 & 22.1 & 7.1 \\
8. Soy meal (extracted) & 40.2 & 41.3 & 40.8 & 3.3 \\
9. Potatoes, peeled & 8.0 & 8.1 & 8.1 & 59.1 \\
10. Swedes, peeled & 1.8 & 1.8 & 1.8 & 1.4 \\
11. Carrots & 59.6 & 60.0 & 59.8 & 3.8 \\
12. Celery & 0.7 & 0.8 & 0.8 & 10.3 \\
13. Luzern & 3.0 & 3.1 & 3.1 & 3.1 \\
14. Rootstocks of horsetail (Eq. palustre) & 9.9 & 10.3 & 10.1 & 10.9
\end{tabular}

determined as glucoseanhydride. The figures in Table 1 obtained with the amyloglucosidase method are results of Salo's work. The present author has made colorimetric estimations from the same samples. It appears that the difference between the parallel results is only in one case higher than 0.5 pct-units. The difference between the colorimetric and amyloglucosidase mean values is only in 4 cases out of 14 higher than one pct-unit, and the amyloglucosidase value is in 10 cases out of 14 higher than the colorimetric value.

In the determinations $15 \mathrm{ml}$ of solution AI (cf. p. 61) was usually used for preparing solution A II. For foods 8, 10, 11 and 13, the corresponging volume was $10 \mathrm{ml}$. As to the food 12, the colour tone in the optical cell B (cf. p. 61) did not become the same as in cell A, $10 \mathrm{ml}$ of the iodine solution instead of $5 \mathrm{ml}$ was used in preparing the solutions AI, BI and C. When estimating the starch from foods 7, 8, 10, 11, 13 and 14, an $1 \mathrm{~g}$ sample was first extracted by boiling in $80-\%$ ethanol in order to reduce the amount of coloured substances. This procedure may have been unnecessary in some of the cases. 
$\mathrm{S}$ t a r ch determination from fa e ces. Sometimes faeces, especially those of swine, contain starch included in food particles which have escaped mastication. It is consequently important that also this starch is estimated. For this reason the author has examined whether some faeces constituents might interfere in the colorimetric starch determination. $100 \mathrm{mg}$ of wheat starch was mixed into $5 \mathrm{~g}$ of fresh cow faeces and the starch determined from the mixture. All added starch was recovered. The result was the same when $50 \mathrm{mg}$ of starch was mixed into $6 \mathrm{~g}$ of faeces. In these cases the mixture was extracted beforehand with $80-\%$ ethanol.

\section{$S u m$ m a r $y$}

In the iodine colorimetric method of Paloheimo gently dextrinized solutions are prepared of pure starch and of the analysis sample. One of the optical cells (A) of the comparator is provided with a solution made of pure starch and the other (B) with the solution to be analysed. Both solutions have the same iodine concentration. The solution in B must have a intensive colour than that in A. Solution B is then diluted with an iodinewater solution of the same iodine concentration as in the solutions A and B. When these solutions have attained the same colour it is concluded that also the starch concentration is the same and the starch content of the sample can be calculated.

The results obtained by this method are compared with those obtained with the amyloglucosidase method of Salo. Table 1 shows that the two methods give very similar results.

Different circumstances which might possibly interfere with the colorimetric starch determinations are studied. - It was observed that attention must be paid to the intensity of boiling when the $0.05-\mathrm{N} \mathrm{H}_{2} \mathrm{SO}_{4}$ dextrinizing solutions are boiled. If the intensity is very different in the comparison solution and the solution to be analysed, considerable errors may occur. - If the sample contains added chalk the neutralizing power of the sample should be determined beforehand and the normality of the solution adjusted to 0.05 . If the sample contains acid it should be extracted beforehand with $80-\%$ ethanol. - Cellulose and sugars have no influence on the results, nor have plant proteins or proteins of milk. However, if greater amounts of protein were added, a casein preparation intended for laboratory animals showed an obvious disturbing effect, as did gelatin and meat protein. - Faeces did not appear to have an interfering influence in colorimetric starch determination.

The iodine colorimetric sensitiveness of starch solutions was also studied. It appeared that $0.18 \mathrm{mg}$ of dextrinized potato starch already deepened the colour of $100 \mathrm{ml}$ dilute iodine solution in room temperature. For wheat starch the corresponding minimum concentration was $0.27 \mathrm{mg} / 100 \mathrm{ml}$. In $3^{\circ}$ the concentration limit was even lower, $0.05-0.09 \mathrm{mg} / 100 \mathrm{ml}$.

In all the above mentioned studies the author has used as comparator essential parts of a Pulfrich photometer. A proper comparator (Fig. 1) can also be made by any skilled optician.

\section{REFERENCES}

Brautlecht, C. A. 1953. Starch, its sources, production and uses. New York. $1-408$.

Palohermo, L. 1930. Zur Verwendbarkeit des jodkolorimetrischen Prinzips bei Stärkebestimmungen. Bioch. Z. 222: $150-172$. 
Palohermo, L. 1948. Determination of starch according to the principle of iodine colorimetry. J. Sci. Agric. Soc. Finland 20: 109-113.

Palohermo, L. und Palohermo, I. 1931. Beiträge zur Jodkolorimetrie der Stärke nach der Methode von Paloheimo. Bioch. Z. 238: 391-400.

SALO, M. - L. and SAlmi, M. 1968. Determination of starch by the amyloglucosidase method. J. Sci. Agric. Soc. Finland 40: 38-45.

SAmec, M. 1927. Kolloidchemie der Stärke. Dresden und Leipzig. 1-509.

\title{
SELOSTUS
}

\section{JODIKOLORIMETRINEN TÄRKKELYSMÄÄRITYS}

\author{
K. A. VaInio
}

\section{Kotieläintieteen laitos, Helsingin yliopisto}

Paloheimon jodikolorimetrisessä tärkkelysmääritysmenetelmässä valmistetaan $0.05-\mathrm{N}$-rikkihapolla heikosti dekstrinoidut liuokset puhtaasta tärkkelyksestä ja analyysinäytteestä (liuokset AI ja BI). Näistä liuoksista tehdään laimennokset, joihin kumpaankin järjestetään sama jodikonsentraatio: saadaan liuokset AII ja BII. Laimennus on suoritettava siten, että BII tulee tummemmaksi kuin AII. Kolorimetrilaseja tarvitaan kaksi, A ja B. Lasiin A otetaan värinäytteeksi liuosta AII. Lasiin B kaadetaan määrätilavuus liuosta BII, joka sitten tärkkelyksen suhteen laimennetaan liuoksella C. Liuos C ei sisällä tärkkelystä, mutta sen jodiväkevyys on sama kuin liuoksen AII ja BII. Liuosta BII laimennetaan asteettain, kunnes värivahvuus kolorimetrilaseissa tulee samaksi. Liuos C:n kulutuksen perusteella voidaan nyt laskea BII:n ja siitä edelleen ko. näytteen tärkkelyspitoisuus.

Kirjoittaja on eräissä suhteissa muuntanut Paloheimon menetelmää. Niinpä on värivertailussa käytetty Pulfrich-fotometrin tarkoitukseen sopivia osia (Kuva 1.) ja liuos C lisätään byretistä. Edelleen on tutkittu tärkkelyksen jodireaktion herkkyyttä, kiehumisvoimakkuuden ja happoväkevyyden vaikutusta dekstrinointikeitossa sekä eräiden tutkittavissa näytteissä mahdollisesti esiintyvien aineiden vaikutuksia. Lopuksi on jodikolorimetrisellä menetelmällä saatuja tuloksia verrattu Salon amyloglukosidaasimenetelmällä saatuihin.

Tärkkelyksen jodireaktio osoittautui erittäin herkäksi. Niinpä $0.18 \mathrm{mg}$ perunan tärkkelystä riitti aikaansaamaan värimuutoksen $100 \mathrm{ml}$ :ssa laimeata jodiliuosta. - Kiehumisvoimakkuudella todettiin olevan varteenotettava vaikutus. - Jos tutkittava aines sisältää $\mathrm{CaCO}_{3}$-lisäyksen, on näytteen neutraloiva vaikutus etukäteen tutkittava ja dekstrinointihappamuus järjestettävä 0.05 -normaaliseksi. Jos näyte sisältää happoja, on se edeltävästi uutettava 80 - \% etanolilla. - Sưretkaan määrät filteripaperia, sokereita, kasvivalkuaista tai maidon valkuaista eivät vaikuta häiritsevästi. Sen sijaan preparoidulla kaseiinilla, liivatteella ja lihavalkuaisella on häiritsevä vaikutus. Lehmän sonnassa ei osoittautunut olevan aineita, jotka haittaisivat tarkkelyksen määrittämistä.

Salon amyloglukosidaasimenetelmä antaa ilmeisesti erittäin luotettavia tuloksia. Tästä syystä tutkittiin jodikolorimetrisen menetelmän pätevyyttä vertaamalla sillä saatuja tuloksia Salon menetelmällä samoista näytteistä saatuihin. Taulukosta 1 nähdään, että näillä kahdella tavalla saadut tulokset ovat keskenään varsin yhtäpitäviä.

Kirjoittajan suorittamat tutkimukset osoittavat, että jodikolorimetrinen menetelmä soveltuu erittäin hyvin tärkkelyksen määrittämiseen. Lisäksi tämä menetelmä on varsin joutuisa. Ilmankin prismoilla ja linsseillä varustettua kolorimetriä, kotitekoista kolorimetrikameraa käyttäen, saadaan tuloksia, joiden tarkkuus on useihin tarkoituksiin riittävä. 